\title{
PARADOXES OF TRANSROBOTISM: AN ANTI-TRANSHUMANIST READING OF CHRIS COLUMBUS'S BICENTENNIAL MAN
}

\begin{abstract}
A bstract. This essay proposes a re-reading of Chris Columbus's film Bicentennial Man (1999) as a critique of transhumanism. Construing the robot protagonist, Andrew Martin, as a metaphor of the human being, the essay argues that the series of modifications he undergoes is a reversed version, as it were, of transformations postulated in Nick Bostrom's "Letter from Utopia" and the Transhumanist Declaration - the famous manifestos of transhumanism. Consequently, the film is interpreted as an affirmation of humanity defined by conservative opponents of transhumanism.
\end{abstract}

Key words: transhumanism—criticism; androids; Chris Columbus; Bicentennial Man; film adaptation; science-fiction cinema.

1.

Chris Columbus's 1999 film Bicentennial Man, based on Isaac Asimov's novella "The Bicentennial Man" (1976) and the novel The Positronic Man (1992), co-authored by Asimov and Robert Silverberg, exemplifies a fascinating cultural paradox. On the one hand, the film has met with a scathing critical response. As aptly summarized by Sue Short, both SF fans and reviewers pointed out Columbus's comic treatment of Asimov's serious questions, as well as "the mawkish sentimentality that overtakes the movie" (209). To these factors, one might add not only complaints concerning the film's tediousness, possibly resulting from its chronologically-organized episodic structure, but also unfavourable comments on the performance of

Andrzej SŁawomir KowalczyK, PhD, DLitt-Maria Curie-Skłodowska University, Faculty of Humanities, Institute of English Studies; address for correspondence: Plac Marii Skłodowskiej-Curie 4A, 20-031 Lublin, e-mail: askowal@poczta.umcs.lublin.pl 
Robin Williams as Andrew Martin, the robot protagonist. With regard to the message, Bicentennial Man was summarized as a "banal vision of the near future" (Higgins), "an impenetrable bubble of hollow humanism" (Schwarzbaum), a film "going for the emotional jugular with drippy, sugar-coated New Age sentiments" (Holden), etc. In the words of another hostile critic, Bicentennial Man is "a film about artificial intelligence, so it's a pity it doesn't show any intelligence, artificial or otherwise" (Tookey 61). ${ }^{1}$

On the other hand, however, the film has been the topic of several critical studies as well as a starting point for serious philosophical, ethical, theological, and forensic considerations (e.g. Buckner Innis; Short; Anderson; Radkowska-Walkowicz; Coleman and Hanley; Kakoudaki; Kowalski; Kwiatkowski). This paradox can perhaps be understood better in light of Christopher Falzon's remarks on the relationship between (popular) cinema and philosophy. In his Philosophy Goes to the Movies, he argues that "films represent a kind of collective visual memory, a vast repository of images, through which many [philosophical] ideas and arguments can be illustrated and discussed" (3). According to Falzon, films can "not only presuppose but also embody a multiplicity of ideas, conceptions of life and action, views of the world and so on" (6, emphasis added). Whereas some films seem to be more philosophically-grounded than others, Falzon is perfectly right in claiming that mainstream cinema and popular genres can raise certain philosophical questions as adequately as what he calls "art house' movies" and “"respectable' genres" (6-7). Importantly, though, the point is not so much to utilize a film in order to illustrate/investigate a certain philosophical problem but rather to "bring [...] out something of what is going on within the films" (Falzon 7).

In view of this, assuming that the robot protagonist of Bicentennial Man can be read as a metaphor of the human being (see below), the present essay aims to re-visit Columbus's film in a new context. Rather than prioritizing the central theme of artificial intelligence and exploring the status of the robot in human society, as has been done so far, I propose to interpret Bicentennial Man as a critical comment on transhumanism-a bio-techno-philosophical movement which has been generating both fascination and a great

\footnotetext{
${ }^{1}$ Browsing through reviews of Bicentennial Man, one may get the impression that the film has served as an ideal pop-culture artefact for critics to demonstrate their wit and rhetorical/literary skill. As a case in point, consider the following summary: "Perhaps, one day, there will be robot film reviewers. And if they beg not to be sent to Robin Williams movies, we'll know they are developing human feelings" (Porter).
} 
deal of controversy since the time it began to appear in contemporary academic discourse.

\section{2.}

In the words of Max More, one of the scholarly proponents of transhumanism, the concept can be understood as "a life philosophy, an intellectual and cultural movement, and an area of study" (4). A nonreligious humanistic philosophy, transhumanism postulates "perpetual progress, self-transformation, practical optimism, intelligent technology, open society, self-direction, and rational thinking" (More 5). According to transhumanists, in the not-so-near future bio-technological development will affect the human organism to such an extent that the humans of today will be transformed into the so-called "posthumans." As Nick Bostrom, another founding father of the movement, explains in his essay "Why I Want to be a Posthuman When I Grow Up," a posthuman is "a being that has at least one posthuman capacity," that is one "greatly exceeding the maximum attainable by any current human being" (28-29). Such a capacity, he argues, concerns health span, cognition, and emotion, not excluding some other possible elements (29). In his better-known "Letter from Utopia," Bostrom waxes lyrical, prophesying the end of death and suffering, and urging "a new kind of life," filled with pleasure, beauty, and good. The letter, addressed to "Dear Human" and narrated/signed by "Your Possible Future Self," appeals to the addressee to "create something even greater" than human life, namely "[1]ife that is truly humane."

It may be a sheer coincidence that Columbus's film entered the cinemas of the Anglophone world a year after the first versions of the Transhumanist Declaration $(1998)^{2}$ were announced. If, however, one accepts Falzon's thesis of (popular) cinema serving as sui generis collective visual memory, it is possible to construe Bicentennial Man as a more or less self-aware reflection on the concurrent philosophical ideas, including transhumanism.

According to the July 1998 version (2.4) of the Transhumanist Declaration, updated in 2002 and 2009, technology is to be a decisive factor responsible for the transformation of the human race. It is to help to eradicate "the inevitability of aging," overcome limits imposed on "human and artificial

\footnotetext{
${ }^{2}$ Henceforth, TD.
} 
intellects," eliminate suffering, as well as transgress "our confinement to the planet Earth." As far as ethics is concerned, the Declaration grants "the moral right for [everyone] to use technology [...] to improve their control over their own lives," biological confines notwithstanding. It is also declared that transhumanism promotes "the well-being of all sentience," including not only humans, animals, and "artificial intellects" but also "possible extraterrestrial species." The movement situates itself within "modern secular humanism," declaring no political engagement. This brief summary provides a major context for the subsequent interpretation of Columbus's adaptation of Asimov's and Silverberg's literary texts.

The film's literary inspirations, the novella "The Bicentennial Man" and the novel The Positronic Man, commence with Asimov's world-famous Three Laws of Robotics. The opening scene, a conversation between a robot surgeon and the android Andrew Martin, whose governing desire is to become a human being, concerns the problem of whether these laws, and especially the principle of not injuring a human being (the First Law) and not obeying the order which violates the First Law (the Second Law), also apply to the human-like (robot) individual. Next, via a series of flashbacks, the reader learns about the two-hundred-year-long existence of the robot protagonist, named simply "NDR-" by its manufacturers, who ${ }^{3}$ - owing to an error in the "positronic pathways" of his brain - has advanced from a mere household assistant to the intellectually superior, emotionally equal, and virtually immortal equivalent of the human being.

This unprogrammed development, utterly surprising to the robot's constructors ("The United States Robots and Mechanical Men Corporation"), involves some key stages, initiated by the manifestation of Andrew's artistic creativity. His owners, the Martins (whose surname Andrew assumes), treat him as a member of the family, which consists of "Sir, Ma'am, Miss, and Little Miss." They make a small fortune on Andrew's art but have half of the profits deposited on his personal account. Meanwhile, the robot is upgraded several times, his brain remaining untouched. Finally Andrew decides to buy his freedom, taking the case to the court and winning it. He begins to wear

\footnotetext{
${ }^{3}$ Taking into account the robot's future development and status as a human being, throughout this essay I refer to him as to a male person and use the corresponding pronouns.
} 
clothes, continues to learn, manages to obtain legal protection for robots, and even authors the first "history of robots [written] by a robot." He uses his influential human friends to demand a major upgrade from his manufacturers, thereby becoming an android, or, to be precise, the android, for he is absolutely unique, the only one of his kind. Even this, however, is not sufficient, and Andrew turns into a "robobiologist" so as to develop "a humanoid organic body."

The ensuing step is to change himself in a robot who can breathe, eat, and even excrete (genitalia being possible as well, "insofar as they will fit [his] plans"), his positronic brain "interacting with simulated nerve pathways." Endowed with an organic body, Andrew holds crucial patents in "prostethology," the new science he has established. The final stage of his quest for becoming a human, conducted "through six generations of human beings," is a legal one, again: Andrew institutes a complicated lawsuit to be granted humanity by "the World Court." Meanwhile, however, returning to the story's present, the reader learns that Andrew undergoes another operation, sacrificing his robotic (or "positronic") immortality in the name of his "aspirations and desires." Andrew realizes that he can be accepted by human society as an immortal robot but never as an immortal human being, so he prearranges his own death, as it were. Finally, "the World President" declares Andrew Martin "The Bicentennial Man," and Andrew departs as an entirely fulfilled individual.

Apparently, emphasis in the two literary texts is laid on the intellectual rather than on the emotional, foregrounding the ethical/moral dilemmas Asimov and Silverberg bring into discussion. In contrast, in Columbus's $\mathrm{Bi}$ centennial Man, the Three Laws do not constitute a crucial starting point. They may be presented by the freshly-unpacked robot (Robin Williams) in what he calls "a most entertaining presentation"-a painfully anachronistic, cinema-like showing, accompanied with village-fair-like music-but are hardly ever recalled for any serious reflection. (Even the robot himself admits that the show, which has frightened the girls, "is a one-time only.") More importantly, the advent of the android - the term being used in its nontechnical sense in the film ${ }^{4}$ - almost immediately polarizes the family members' attitudes. While Mr Martin (Sam Neill), or Sir, is clearly fascinated

\footnotetext{
${ }^{4}$ Generally, encyclopaedias of science fiction propose more precise definitions: an android is "a synthetically created human, usually of organic or biological origin" (Mann 462, emphasis added); "a kind of robot constructed of organic rather than mechanical parts (D'Ammassa 435, emphasis added).
} 
with the new acquisition, and his wife (Wendy Crewson), or Ma'am, is rather reluctant, ${ }^{5}$ the older daughter (Lindze Letherman), or Miss, hates the robot ("It's stupid!"), whom the younger daughter (Hallie Kate Eisenberg), or Little Miss, gradually befriends. It is her, as a matter of fact, who gives Andrew his name, mispronouncing the difficult word "android."

Andrew's role in the family is one of a cook, waiter, cleaner, gardener, nanny, and such like-in a nutshell, a servant, or "robot" per se. ${ }^{6}$ From this viewpoint, it is important to note, after Kakoudaki, that Andrew's being "born" as an adult "becomes the necessary precondition for [his] immediate entry into preordained social or workplace functions" (117). However, the first steps of his education with the Martins resemble those of a child (cf. Dmitruk 69): he makes more or less hilarious linguistic mistakes, misunderstands everyday situations, and often acts awkwardly. It takes Andrew several years to develop a sense of identity, which manifests itself grammatically in referring to himself: the robot replaces the impersonal "one" ("Hello, are you one's family?") with the pronoun "I" ("Called or uncalled, I am always at your service"7). Andrew's affinity with Little Miss further augments the claim that in spite of his crude metallic body, the robot can be construed as an equivalent of the human being, or, in more general terms, as a mirror reflecting the condition of our humanity (Radkowska-Walkowicz 23-24). Similarly, discussing the scene of Andrew's coming to the Martins in a coffin-like box and being subsequently animated by Sir by virtue of a remote, Kakoudaki argues that the episode "reverse[s] the dissolution of human identity, thus providing an attractive if impossible palindromic view of human life" (54). The impression of Andrew's being "humanized" may also result from the contrast between the futuristic assembly line shown during the opening credits and his technologically unsophisticated, Robin-Williamslike appearance. ${ }^{8}$

\footnotetext{
${ }^{5}$ According to another malicious review, she "always looks as though she's waiting for Robin [Williams] to re-enact the computer/human rape scene from Demon Seed" (Clevenger and Zollinger 135).

${ }^{6}$ The word "robot" comes from the Czech noun robota, denoting physically demanding labour. The word was first applied to fictional, factory-produced human-like creatures shown in the play R.U.R. (Rossumovi Univerzálni Roboti) (1920) by Karel Čapek. The word was popularized in the 1920s, after the play was translated into English (Konefał 43-44).

7 The significance of this moment is underscored by Mr Martin, who says: "Andrew, you stopped referring to yourself as one!'”

${ }^{8}$ In his review, Higgins talks about "[t]hat stocky frame, those restless eyebrows, the characteristic simper set in a metallic rictus."
} 
The figurative link between the film's robot and the human being established, I propose to consider Andrew's case with reference to Bostrom's "Letter from Utopia" and the Transhumanist Declaration - the manifestos of transhumanism. In his essay, Bostrom postulates the three "fundamental transformations," or necessary steps on one's path to Utopia, urging the reader to (i) "Secure life!"; (ii) "Upgrade cognition!"; and (iii) "Elevate well-being!" ("Letter"). As far as life is concerned, Andrew may represent an already-transformed being: he does not age, is resistant to such "assassins" (Bostrom's term) as infection, terminal diseases, malnutrition, and violence, as well as being able not only to service himself but also to have his positronic mind "moved to more durable media" (Bostrom, "Letter"). While the most important people around him-like Sir or Little Miss-die, Andrew is practically unaffected by the passing of time. Illness and senescence, the two problems Bostrom calls to eradicate ("Letter"), do not concern the human-shaped robot.

And yet, paradoxically enough, the status quo is far from making the protagonist satisfied. On the contrary, Andrew resolves to undergo a series of actions to reverse his superior "utopian" condition: from his wish "to have more expression" on his metallic face to articulate "thoughts and feelings that presently do not show," and from making his face and fingers more human-like by having a malleable substance applied to them by one Rupert Burns (Oliver Platt), an eccentric, somewhat "alternative" genius of robotics, ${ }^{9}$ to the complete overhaul-Andrew's becoming an android, that is a robot with organic parts and his own neural system, which also takes place in Rupert's laboratory. It is precisely owing to this merger of technology and bio-technology that Andrew can epitomize, in a manner, the transhumanist principle of "redesigning the human condition" (TD, para. 1) and being "generally open and embracing of new technology" (TD, para. 3) so as to "extend [one's] mental and physical capacities and to improve [one's] control over [one's] own li[fe]" (TD, para. 4). ${ }^{10}$ Along the line of thinking of transhumanist prophets, Andrew "take[s] into account the prospect of dramatic technological progress" (TD, para. 6). The progress, it must be added,

\footnotetext{
${ }^{9}$ The viewer learns that Rupert's father used to work for NA Robotics (i.e. Andrew's manufacturer), doing research on androids - the branch which was abandoned due to negative market response. He designed the technology of mimicking human expression which was later applied to Andrew.

${ }^{10}$ In the film, Rupert aptly calls the prospective change "a profound transition from the mechanical to the biological" (emph. added).
} 
which — thanks to Rupert's "design, or modification"- eventually allows him not only to be able to experience the smell and taste of food (and, far less pompously, to flatulate) but also to fall in love and have a fiery (?) sexual relationship with Little Miss's granddaughter, Portia (played by Embeth Davidtz, who also plays the older Little Miss). ${ }^{11}$ Though the official marriage between the two is impossible ("If we're together, you and me, we'll never be accepted"), it can be inferred that their relationship flourishes, which gives Andrew the incentive to start his legal battle to be declared a human.

Later on, however, when Portia is seventy five but, as Andrew himself notices, due to bio-technological improvements ("DNA elixirs") looks like she were fifty, she actually feels weary of her improved life. "Human beings," she explains to Andrew, "are meant to be here for a certain time and then pass on; that's what's right" (emph. added). Thus, the transhumanist vision of eternal youth may become dangerously close to Jonathan Swift's depiction of struldbrugs, for whom immortality is a curse. Andrew's pivotal decision to have human blood introduced into his system, as a result of which the indestructible components of his organism begin to wear away, may seem a regress, or a backward transformation, but the act brings him closer to Portia and, indirectly, to Little Miss - the women he has loved. "I would rather die as a man," Andrew declares, "than live for all eternity as a machine." The film's final scene showing Portia and Andrew peacefully dying next to each other in a state-of-the-art room is mawkish indeed, and the protagonist passes away seconds before the "World Congress's" declaration of his being a human is announced. Nevertheless, it conveys yet another message which corroborates the film's anti-transhumanist interpretation. Namely, Portia asks the android nurse Galatea ${ }^{12}$ to switch off the machinery

${ }^{11}$ The weird nature of this relationship has not escaped critics' attention. For instance, Higgins talks about "a nasty taste in the mouth [which appears] precisely because we're asked to consider as straightforwardly romantic a cross-generational, quasi-incestuous relationship between a 150-yearold robot and a young woman" (emph. added). For a more jeering (and risqué) comment, see Clevenger and Zolinger.

${ }^{12}$ Galatea is a version of the NDR robot with the so-called "personality chip." Modified/ upgraded by Rupert, she becomes his companion and (household) servant, her name being an ironic allusion to the Greek myth of Pygmalion, a sculptor who created a statue of a woman and fell in love with it. Apparently, Galatea is a female equivalent of Andrew, met at the end of his long search for a similar robot. However, as she is hard-wired (and thus not only stupid but also annoying), Galatea frustrates Andrew's expectations to find a suitable friend/partner. When Andrew removes her personality chip to make her more independent, Galatea rebels against her human master; nevertheless, she does it in a mechanical, superficial manner: "And I'm sick of it! All day long it's, 
which maintains the elderly woman's life. The female robot does it, consciously violating Asimov's First Law. Her rebellious action, accompanied with tears in her eyes, is ironically summarized with a phrase Andrew used to utter as a "standard" household servant: "One is glad to be of service." The freedom of choice, or breaking the android's pre-programmed principles, is thereby associated with the freedom to perish, death being affirmed as a relief and the natural culmination of human existence.

To return to "Letter from Utopia," its second recommendation concerns cognition. Among the special faculties of the human brain that Bostrom enumerates are "music, humor, spirituality, mathematics, eroticism, art, nurturing, narration and gossip" ("Letter"). Except for spirituality, all the other examples characterize Andrew's development. The robot does improve his positronic brain, going far beyond the limits set by his manufacturers: for instance, the viewer witnesses Andrew's learning how to joke, entertain others, and sound ironic; how to enjoy music and play the piano with Little Miss; how to carve from wood various beautiful objects and build more intricate designer clocks; how to blueprint and construct a house; how to describe his own experience and quest for fellow-robots; how to create artificial organs, uniting medicine with high-tech ("I downloaded every known medical text into my memory [and] I studied them"); how to speak in front of multinational public; how to read the biological signals of the human body ("Your pulse," he says to Portia, "just jumped from 66 to 102 beats per minute; your respiration rate is doubled"); and even how to gossip about Portia's fiancé, Charles ("a man whose face closely resembles an antique can opener").

And yet, Andrew's knowledge, clearly surpassing that of any other human being, proves insufficient to make him find fulfilment in it. Or, rather, it is too perfect and too complete to make him happy - in a human sense. Portia attempts to explain it to the protagonist in an emotionally-loaded scene where she announces that she is getting married to Charles and finds Andrew-jealous as he is - to take the message with no emotional reaction: "If you're going to succeed [...] you've got to stop being so damn deferential." She insists that "sometimes it's important not to be perfect; it's important to do the wrong thing!" (emphasis added). As an android, Andrew

\footnotetext{
'Yes Rupert, sir! No Rupert, sir! Would you like another beverage Rupert sir?' And it chaps my ass!" In this light, her final physical and psychological transformations (i.e. her becoming a sensu stricto android and being so autonomous as to break the Laws of Robotics) may augment the film's anti-transhumanist message.
} 
has an equivalent of the heart which, as Portia observes, can even be felt, but in order to become a human - and, perhaps, in order to make her change her mind about the marriage, for she has begun to be emotionally committed to Andrew-he must make mistakes. The point is not so much to learn from them as to "find out what's real and what's not, to find out what [one] feel[s]." This definition of the essence of humanity can be regarded as overemotional and superficial; nevertheless, it can appeal to the viewer's empathetic qualities. ${ }^{13}$ Likewise, much later, at the end of Andrew's suicidal blood transfusion, Rupert observes: "Someone becomes a human being, sooner or later they do something monumentally stupid." With regard to transhumanist propositions, and especially to Bostrom's urge that "your brain must grow beyond the bounds of any genius of humankind, in its special faculties as well as its general intelligence" ("Letter"), it seems that Andrew's happiness is dependent not so much on his super-human capacities of the designer of bio-mechanical organs but rather on elementary emotional bonds with other people. It is true that thanks to his positronic pathways Andrew "may better learn, remember and understand" ("Letter") but whether he "apprehend[s] [his] own beatitude" ("Letter") because of his supreme capacities is questionable.

The third transformation described by Bostrom aims at pleasure, which "pervades into everything [citizens of the Transhumanist Utopia] do and everything [they] experience" ("Letter"). From a perspective, Andrew's life with the Martins is comparable to Bostrom's state of Utopia, defined as "your home," and "the place where you belong" ("Letter"). At first, Andrew does not feel any suffering, nor does he seem uncomfortable with his hardwired household-servant role: "One is glad to be of service" (emphasis added). The people he finds around him after his start-up procedure (shown from the robot's viewpoint) are immediately appropriated, as it were: "Hello! Are you one's family?" Despite the fact that during the night he has to rest in the cellar, Andrew does not object — and why should he? - requiring a source of power only. Bostrom's "Letter" posits that pleasure ("fun") is "the bright right of every creature." Likewise, the Transhumanist Declaration "advocates the well-being of all sentience." In the film, Mr Martin's elderly daughter's practical "joke" of ordering Andrew to jump out the window to prove how stupid robots are (and, perhaps, to cause Andrew's irrepa-

\footnotetext{
${ }^{13}$ The episode can be viewed in terms of the should-I-listen-to-my-heart question, typical of romantic novels and films. Accordingly, what Portia says to Andrew applies to herself.
} 
rable damage to get rid of him) is immediately rebuked by the father. Sir reprimands his daughter, explaining to both girls that "Andrew is not a person $[\ldots]$ but from now on as a matter of principle in this family [he] will be treated as if he were a person" (emphasis added). Andrew's own "well-being" with the Martins is also reflected in the scene where he rescues a spider found in the cellar, the camera zooming on his mechanical hand setting the insect free onto white petals.

Nevertheless, in the course of his development, the robot advisedly chooses to resign from (perpetual) happiness and decides to experience also the emotions which are "profoundly intense and difficult to tolerate," as Rupert puts it. When Little Miss dies, Andrew considers it to be "cruel" that Portia can cry and he cannot, while he feels "a terrible pain [he] cannot express." The emotional consequences of Andrew's choice to have a humanlike neural system manifest themselves fully in his legal campaign for being recognized as a human being. At first, his claim is disdainfully rejected. "You are something else, something artificial," says the chairman of the World Court, conclusively declaring Andrew Martin "a robot, a mechanical machine, nothing more." Andrew's disillusionment and unhappiness find expression in his turning away with the familiar phrase: "One is glad to be of service," pronounced with bitter irony.

Many years later, the action is repeated, Andrew now looking like an elderly man, his hair turned white, his face liver-spotted and wrinkled, and his voice more feeble - an antithesis of transhumanists' vision of perpetual pleasure and happiness. After stating his arguments in front of the Congress and Madam Chairman - a black woman, and thus a representative of the once-persecuted minorities-Andrew explains that he has attempted to be acknowledged for what he is "not for acclaim, not for approval but for the simple truth of that recognition" (emphasis added), also mentioning the concept of dignity. This makes him particularly close to those critics of transhumanism who, like Francis Fukuyama in his well-known book Our Posthuman Future: Consequences of the Biotechnology Revolution, stress the role of dignity in defining humanity. Invoking Aldous Huxley's Brave New World, Fukuyama observes:

the people in [the novel] may be healthy and happy, but they have ceased to be human beings. They no longer struggle, aspire, love, feel pain, make difficult moral choices, have families, or do any of the things that we traditionally associate with being human. They no longer have the characteristics that give us human dignity. (6) 
And although transhumanists do not overtly postulate creating a Huxleian brave new world, their optimistic fascination with what they call "the posthuman modes of being" (Bostrom, "Why I Want" 29) may raise numerous reservations, whose simplified, pop-culture equivalents can be noticed in Columbus's film. In general, while Bostrom asserts that these new modes of being "would be very good" ("Why I Want" 29, emphasis added), the assumption behind Andrew's life-long quest is the opposite: as a matter of fact, it is being (declared) a human which is the greatest value per se-one literally worth dying for.

4.

To conclude, as a metaphor of the human being, Andrew-the-postrobot, who corresponds to the transhumanists' posthuman, epitomizes the greatest failure of his continuous transformations, or life-long upgrading. First, his practically indestructible and self-serviced body is changed for a much more sophisticated but vulnerable one, making him dependent on Rupert (or another high-tech genius) in all stages of his existence, and finally leading him to bodily deterioration and unavoidable (and, in a manner, unforeseeable) death. Second, Andrew's unique intellectual and artistic capacities do not make him live an enjoyable, "utopian" life; paradoxically, it is such traditional social bonds as family, friendship, and marriage which provide a human with a sense of fulfilment. Third, the protagonist's positronic brain, initially impervious to negative emotional experience, becomes wired with an artificial nervous system; as a result, Andrew is prone to different kinds of suffering, from contempt and rejection, and from jealousy to grief. Thus, the overall message of Columbus's Bicentennial Man can be read as an affirmation of the conservative understanding of humanity, even though simplified for the requirements of popular cinema.

\section{WORKS CITED}

Anderson, Susan Leigh. “Asimov's 'Three Laws of Robotics' and Machine Metaethics.” AI \& Society 22 (2008): 477-493. Print.

Asimov, Isaac and Robert Silverberg. The Positronic Man. New York: Doubleday, 1993. EPUB file.

Asimov, Isaac. "The Bicentennial Man." The Bicentennial Man and Other Stories. New York: Doubleday, 1976. EPUB file. 
Bicentennial Man. Dir. Chris Columbus. Buena Vista Pictures, 1999. DVD.

Bostrom, Nick. "Letter From Utopia." 2008, 2010. Web.

. "Why I Want to be a Posthuman When I Grow Up." The Transhumanist Reader. Ed. Max More and Natasha Vita-More. Oxford: Wiley-Blackwell, 2013. 28-53. Print.

Buckner Inniss, Lolita K. "Bicentennial Man - The New Millennium Assimilationism and the Foreigner among Us.” Rutgers Law Review 54 (2002): 1101-1132. Print.

Clevenger, Scott and Sheri Zollinger. Better Living through Bad Movies. Lincoln: iUniverse, 2006. Print.

Coleman, Stephen and Richard Hanley. "Homo Sapiens, Robots, and Persons in I, Robot and Bicentennial Man." Bioethics in the Movies. Ed. Sandra Shapshay. Baltimore: The Johns Hopkins University Press, 2009. 44-55. Print.

D’Ammassa, Don. Encyclopedia of Science Fiction. New York: Facts On File, 2005. Print.

Dmitruk, Natalia. "Are You Really a Child? Androids and Cyborgs in Japanese Comics and Animations." Androids, Cyborgs, and Robots in Contemporary Culture and Society. Ed. Steven John Thompson. Hershey: IGI Global: 2017. 65-95. Print.

Falzon, Christopher. Philosophy Goes to the Movies: An Introduction to Philosophy. London: Routledge, 2002. Print.

Fukuyama, Francis. Our Posthuman Future: Consequences of the Biotechnology Revolution. New York: Farrar, Straus and Giroux, 2002. Print.

Higgins, Mike. "Bicentennial Man reviewed by Mike Higgins.” 20 December 2011. Web.

Holden, Stephen. "Bicentennial Man: So Hard on the Outside, but Such a Softy Within." The New York Times on the Web. 17 December 1999. Web.

Kakoudaki, Despina. Anatomy of a Robot: Literature, Cinema, and the Cultural Work of Artificial People. New Brunswick: Rutgers University Press, 2014. Print.

Konefał, Sebastian Jakub. Corpus Futuri: Literackie i filmowe wizerunki postludzi. Gdańsk: Wydawnictwo Uniwersytetu Gdańskiego, 2013. Print.

Kowalski, Dean A. Classic Questions and Contemporary Film: An Introduction to Philosophy, 2nd ed. Chichester: Wiley Blackwell, 2016. Print.

Kwiatkowski, Fryderyk. “'Let Us Make ROBOT in Our Image, According to Our Likeness': An Examination of Robots in Several Science Fiction Films through the Christian Concept of the 'Image of God'." Studia Religiologica 49.3 (2016): 219-230. Print.

Mann, George, ed. The Mammoth Encyclopedia of Science Fiction. London: Robinson Publishing, 2001. Print.

More, Max. "The Philosophy of Transhumanism." The Transhumanist Reader. Ed. Max More and Natasha Vita-More. Oxford: Wiley-Blackwell, 2013. 3-17. Print.

Porter, Edward. "Bicentennial Man.” The Sunday Times, 23 January 2000. EBSCOhost. Web.

Radkowska-Walkowicz, Magdalena. Od Golema do Terminatora: Wizerunki sztucznego czlowieka w kulturze. Warszawa: Wydawnictwa Akademickie i Profesjonalne, 2008. Print.

Schwarzbaum, Lisa. "Movies.” Entertainment Weekly 520. 7 January 2000: 46. EBSCOhost Web.

Short, Sue. "The Measure of a Man?: Asimov's Bicentennial Man, Star Trek's Data, and Being Human." Extrapolation 44.2 (2003): 209-223. Print.

Tookey, Christopher. Named \& Shamed: The World's Worst and Wittiest Movie Reviews, from Affleck to Zeta-Jones. Matador, 2010. Print.

“Transhumanist Declaration.” H+pedia. 2 January 2016. Web. 


\section{PARADOKSY TRANSROBOTYZMU: \\ ANTY-TRANSHUMANISTYCZNE ODCZYTANIE CZŁOWIEKA PRZYSZŁOŚCI CHRISA COLUMBUSA}

Streszczenie

Artykuł proponuje odczytanie filmu Chrisa Columbusa Człowiek przyszłości (Bicentennial Man) (1999) jako krytykę transhumanizmu. Rozpatrując głównego bohatera — androida znanego jako Andrew Martin - jako metaforę człowieka, artykuł postuluje spojrzenie na modyfikacje, które przechodzi tytułowy bio-mechaniczny „człowiek przyszłości” w kontekście „odwrócenia” transformacji opisywanych w Deklaracji Transhumanistycznej oraz w słynnym „Liście z Utopii” Nicka Bostroma - jednego z czołowych przedstawicieli transhumanizmu. Przyjęte założenia pozwalają na „konserwatywne” odczytanie Człowieka przyszłości jako swoistej afirmacji człowieczeństwa.

Słowa kluczowe: transhumanizm — krytyka; android; Chris Columbus; Człowiek przyszłości; adaptacja filmowa; kino science-fiction. 